UDC: $821.163 .41: 371.3: 373.3 / .4$

Мр Марија М. Бјељац

ОШ „Бора Станковић“, Каравуково

masabjeljac@gmail.com

\title{
МЕТОДИЧКИ ПРИСТУП НАСТАВНОЈ ЈЕДИНИЦИ ДУШКО РАДОВИЋ „КАПЕТАН ЏОН ПИПЛФОКС“ КРОЗ ПРИМЕНУ АКТАНЦИЈАЛНОГ МОДЕЛА
}

\author{
Anстракт
}

\begin{abstract}
Рад представља наставно тумачење одломка књижевног дела „Капетан Џон Пиплфокс“ Душка Радовића који се обрађује у петом разреду основне школе. Посебна пажња посвећена је драмском извођењу одломка чији је циљ да мотивише ученике за читање целог дела, али и за активно учествовање у анализи одломка. Истиче се и значај примене актанцијалног модела у процесу анализе дела, диференциране наставе и вршњачке подршке, који пружају наставнику могућност да драмски књижевни текст обради на занимљив и креативан начин и тако мотивише ученике за читање књижевних дела, али и омогући ученицима да активно учествују на часу обраде. Кроз корелацију редовне наставе српског језика и ваннаставних активности, луткарске секције, код ученика се буди свест и љубав према сценској уметности.
\end{abstract}

Кључне речи: обрада одломка, актанцијални модел, диференцирана настава, вршњачко учење, луткарска представа, луткарска секција.

\section{1. УВОД}

Одељење је истовремено и образовна и вршњачка група. Као образовна група, одељење функционише у складу са одређеним планом рада и нормама које регулишу остварење тог плана. Ученици истог одељења заједно пролазе кроз све наставне ситуације. Као вршњачка група, одељење је група у којој ученици спонтано и под утицајем ситуационих момената ступају у међусобну интеракцију. Та интеракција је усмерена на задовољавање личних и социјалних потреба, успостављање заједничких циљева, стандардизацију групних норми и очекиваних понашања појединаца у групи. Вршњачке 
функције одељења појављују се, обликују и мењају у складу са узрасним потребама ученика и њиховим виђењем и разумевањем школске ситуације, захтева и поступака наставника, педагошког вођења наставних и ваннаставних активности. Иако је група, одељење у свим важним пословима функционише као скуп независних појединаца који паралелно обављају исте или у начелу еквивалентне задатке или активности (Хавелка 2000: 25). Имајући на уму све специфичности одељења наставник кроз примену различитих облика диференциране наставе може да осмисли и организује час обраде, утврђивања, вежбања тако да поштује специфичности сваког ученика. Кроз примену индивидуализоване наставе, као једног од облика диференциране наставе, наставник поштује потребе и могућности сваког ученика, а применом вршњачког учења остварује се комуникација међу ученицима која има позитиван и подстицајан карактер.

\section{2. АКТАНЦИЈАЛНИ МОДЕЛ И ВРШЊАЧКО УЧЕЊЕ}

У редовној настави српског језика драмска дела која се обрађују усклађена су са узрастом ученика. Наставник у планирању и припремању часова осмишљава годишње и месечне планове у којима је истакнут редни број наставне теме, редни број часа, наставна јединица и могућа корелација, тип часа, облици рада, методе, место рада и наставна средства која наставник планира да користи током реализације часа. У плановима се затим наводе: иновације, (само)евалуација и колона у којој се могу навести образовни стандарди који ће се применити на часу, а у складу са наставном јединицом. У оперативном (месечном) плану рада наставник за све наставне јединице даје само основне идеје везане за реализацију часа. У дневним припремама те идеје из оперативних (месечних) планова наставник даље разлаже и детаљно осмишљава час. Избор наставних метода, наставних средстава, облика наставног рада, место рада, иновације зависе од наставника, његових способности, његове воље, креативности, иновативности, па и знања.

Како би се драмска дела у редовној настави српског језика обрађивала на квалитетан, креативан и иновативан начин наставник мора да уложи пуно времена у осмишљавање и планирање часа. Неопходно је да мотивише ученике, да подели задужења, да испланира радне задатаке за ученике, да води рачуна о сваком ученику посебно како би ускладио захтеве са способностима ученика. Важно је да сви ученици буду активни на часу, да сви учествују у усвајању нових садржаја, да примењују раније стечена знања. 
Најчешће се на часовима редовне наставе драмски текст обрађује тако што наставник након мотивације ученика, која је углавном везана за неку анегдоту из пишчевог живота, карактер главног лика или тему дела, најављује тему часа, а затим дели улоге, ученици на тај начин читају драмски текст, затим следи класична анализа дела уз откривање основних елемената: књижевни род, књижевна врста, тема, ликови, карактеризација ликова, поруке... Ако се дело обрађује два часа онда ученици одслушају звучни запис драмског дела или одгледају видео-запис. Када време и могућности дозвољавају наставник води ученике у позориште да одгледају представу ако је на репертоару. Овакав начин обраде драмског дела занимљив је ученицима петог разреда кад се они озбиљније уводе у драму и сценску уметност, али већ током обраде другог или трећег драмског дела интересовање ученика, мотивација, залагање на часу слабе. Зато је важно да наставник има различите приступе обради драмских текстова.

Један од могућих начина је актанцијални модел о коме говори Ан Иберсфелд, а који се може примењивати у редовној настави српског језика и помоћу ког наставник може ученицима да приближи драмска дела увек на другачији начин. Кроз примену актанцијалног модела ученици драмско дело почињу да схватају на један нов и другачији начин и приступ сваком следећем драмском делу биће и нови изазов за ученике.

Актанцијални модел је покушај да се створи универзални модел драмског сукоба. Ан Иберсфелд инспирацију прво налази у тезама руског лингвисте Владимира Пропа у функцијама бајке (Морфологија бајке, 1928), а затим развија тај модел под утицајима студија француског семиотичара Алгирдаса Гремаса.

Гремасов модел се састоји од шест актанцијалних функција (кућица), сврстаних у три пара:

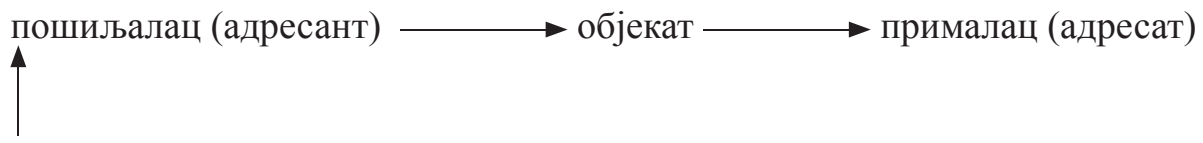

помоћник $\longrightarrow$ субјекат $\longrightarrow$ противник

Осовина «пошиљалац - прималац», према Гремасу, контролише вредност (идеологију), отуд се назива осовином сазнања и/или моћи, док се осовина «субјекат - објекат», која показује трагање јунака назива «осовина жеље», најзад, осовина «помоћник - противник» помаже или омета комуникацију. 
Ан Иберсфелд, у књизи Читање позоришта примењује Гремасов модел на драму и позориште, али уноси важну измену, замењујући места термина на осовини «субјекат - објекат»:

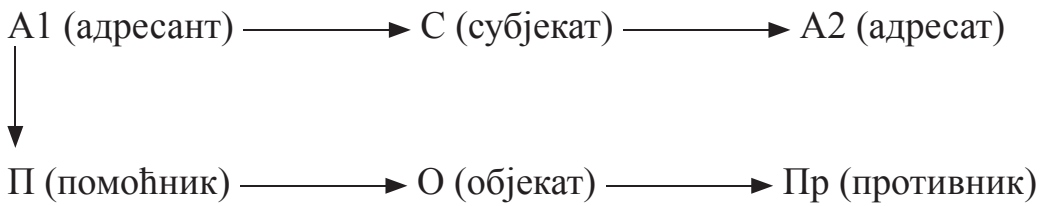

Објекат постаје функција односа помоћника и противника, док субјекат постаје зависан од релације адресанта и адресата. Ауторка образлаже овакву поставку најпре тврдњом да пар «помоћник - противник» треба усмерити најпре ка објекту, «будући да се субјекат ствара најпре око објекта».

Друго, без обзира што је свесна како «адресант, па чак и адресат у крајњем случају помоћник или противник, могу бити апстрактни», док је «субјекат увек живо биће», Иберсфелдова одбацује самосталност функције субјекта. Пошто субјекат делује на подстицај адресанта (често апстрактног начела или неке вредности), а то деловање је усредсређено на објекат, Иберсфелдова логично долази до закључка како «не постоји аутономни субјекат текста, већ оса субјекат - објекат». С једне стране, субјекат је «оно или онај око чије се жеље организује радња», с друге, пак, завршна и темељна формула драмског сукоба гласи: «А1 хоће да (С жели О) у корист А2», то јест - по налогу адресанта, субјекат тежи да задобије објекат у корист адресата. Треба напоменути да, слично Гремасу, Ан Иберсфелд дефинише - на нивоу «површинске» (дискурзивне) структуре текста - актера, као партикуларизацију једног актанта» (Јованов 2014: 65).

Актанцијални модел Ан Иберсфел може да се користи у редовној настави српског језика за тумачење драмских дела, а посебно за анализу ликова. Кад наставник ученицима објасни однос адресант, субјекат, адресат, помоћник, објекат, противник кроз схематски приказ ученици ће лако моћи актанцијални модел да примене на конкретно драмско дело, да открију проблем драмске ситуације и ураде детаљну анализу ликова.

Пре него што ученици почну да примењују актанцијални модел наставник је дужан да их упозна са карактеристикама поменутог модела. Важно је ученицима скренути пажњу на чињеницу да једно лице може да има више функција. Могуће је и да нека кућица буде празна (одсуство, на пример, помоћника). Субјекат се ствара око објекта, помоћник може бити и противник субјекта и објекта. Адресант, адресат, помоћник и противник могу бити апстрактни, док је субјекат увек живо биће. 
Актанцијални троуглови настају када нису у функцији све кућице актанцијалног модела. Ученици актанцијални модел могу да прикажу и помоћу мапа ума. Није неопходно да наставник ученике детаљно упознаје са типовима троуглова зато што тумачење може да да и наставник током анализе ученичких истраживања. Важно је да наставник ученику даје јасне смернице за рад и да упозна ученике са основним елементима актанцијалног модела.

Настава подразумева комуникацију између ученика и наставника и на овој врсти комуникације се посебно ради како би резултати рада били добри. Сваки наставник негује ову врсту комуникације и труди се да на том пољу да свој максимум. Комуникација која се запоставља, а која је изузетно значајна јесте комуникација на релацији ученик - ученик. Утицај који вршњаци имају једни на друге веома је велик и може да послужи као мотивација за боља постигнућа ученика. Вршњачка група омогућава развој интелектуалног, емоционалног и социјалног дела личности. Вршњачко учење може да се примени на свим нивоима образовања ако се прилагоди узрасту ученика и циљевима наставе. Ученици заједно решавају задатке и том приликом помажу једни другима делећи информације, појашњавајући градиво... Кроз групни рад, рад у паровима или кроз рад на пројекту најбоље се остварује вршњачко учење. Разлике које постоје међу ученицима у вршњачком учењу се користе као ресурс за подршку у учењу. Улога наставника у вршњачком учењу је веома важна. Наставник покреће процес узајамне подршке међу ученицима и координира рад. Наставник има улогу ментора, саветника и сарадника, а главне активности су на ученицима и резултати рада зависе од добре међувршњачке сарадње. У оваквом процесу учења имамо ученике који подучавају и ученике који уче, а овакав рад омогућава да обе групе ученика буду активне. Резултати до којих се долази кроз примену вршњачког учења су позитивни било да се вршњачко учење примењује у редовној настави или у вананставним активностима. Кроз примену вршњачког учења ученици са тешкоћама могу да буду мотивисани и да покажу значајан напредак у савладавању градива, али и да покажу веће интересовање за наставни предмет, као и већу ангажованост на часовима и када се вршњачко учење не примењује.

Радио-драма „Капетан Џон Пиплфокс“ Душка Радовића обрађује се у петом разреду основне школе. Након мотивационог разговора и упознавања ученика са одломком који се налази у Читанщи, наставник почиње анализу дела примењујући актанцијални модел. 


\section{3. МЕТОДИЧКИ ПРИСТУП}

Наставник тему часа најављује раније и бира ученике који ће одломак из Читанке спремити за сценско извођење. Током избора ученика наставник води рачуна да у сценски наступ укључи и ученике са посебним потребама (ученици са тешкоћама у учењу и надарени ученици). Овакав избор ученика омогућава примену вршњачког учења.

\section{Циљеви:}

\section{Образовни циљеви:}

* проширивање ученичких знања везаних за живот и стваралаштво Душка Радовића;

* упознавање ученика са карактеристикама драме;

* упознавање ученика са карактеристикама дела;

* упознавање ученика са термином актанцијални модел и његовим карактеристикама;

* подићи на ниво разумевања и примене термине сцена, драмски сукоб, ликови, језик драме кроз директно учешће ученика у драмском извођењу одломка.

\section{Васпитни циљеви:}

* развијати моћ запажања и закључивања код ученика;

* развијати потребу за новим сазнањима;

* подстицати знатижељу;

* развијати потребу за читањем драмских текстова;

* развијати љубав према позоришту, богатити духовну културу;

* изграђивати поглед на свет уочавањем односа: добро - зло, памет - глупост.

\section{Практични (функционални) циљеви:}

* примењивати раније стечена знања и повезивати их са новим знањима и искуствима;

* оспособити ученике за доживљавање и драмско извођење књижевних одломака;

* оспособљавање ученика за уочавање потреба за вршњачком подршком и пружање исте.

Наставне методе: монолошка, дијалошка, текст метода, демонстративна, истраживачка, аналитичка метода.

Облици наставног рада: индивидуални, фронтални, групни рад, рад у паровима

Наставна средства: визуелна, текстуална, акустична 


\section{Временска структура часа:}

\section{Уводни део (10 минута):}

У уводном делу часа група ученика која је раније добила задужења за припрему сценског наступа ученицима приказује скеч. Након краће психолошке паузе следи кратак разговор о утисцима одгледаног скеча, о начину глуме, сарадњи и подршци ученика. Затим ученици сачињавају белешку о животу и стваралаштву Душка Радовића на основу података који се налазе у Читаниц.

\section{Главни део (30 минута):}

Након одгледаног скеча и упознавања ученика са одломком који се налази у Читанци наставник почиње анализу дела примењујући актанцијални модел.

Током анализе „Капетана Џона Пиплфокса“ наставнк ученике дели у три групе и од сваке групе захтева да направи актанцијални модел из кога ће се видети однос ликова и динамика радње. Током поделе ученика у групе води се рачуна о способностима и интересовањима ученика. Прву групу чине ученици који показују основни ниво знања, али у ову групу наставник укључује и једног ученика који показује велико интересовање за предмет, одлично знање и добре резултате. Другу групу чине ученици који задовољавају средњи ниво знања, а и у ову групу је укључен један ученик који показује велико интересовање за предмет, одлично знање и добре резултате. Трећу групу чине ученици који задовољавају напредни ниво знања и у ову групу је укључен један ученик који показује велико интересовање за предмет, одлично знање и добре резултате. Укључивањем ученика који показују одлично знање, добре резултате на тестовима, усменим проверама, на часовима обраде новог градива, али и таленат и смисао за предмет и на тај начин превазилазе и критеријуме за напредни ниво знања омогућиће наставнику да оствари вршњачко учење. Ови ученици ће имати улогу водитеља у групном раду и кроз рад у паровима или индивидуални рад члановима групе ће омогућити да лакше и боље схвате, а затим и примене актанцијални модел. Пре него што наставник да задатке за групе објашњава актанцијални модел.

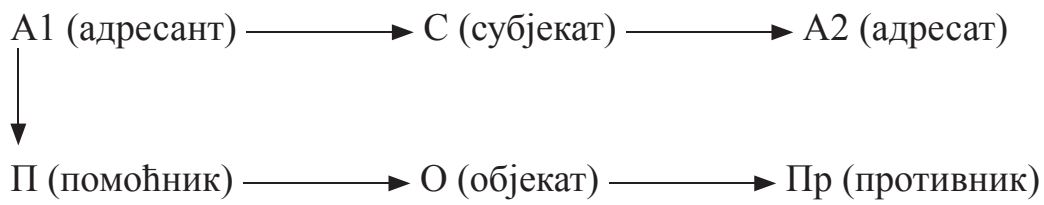


Пар помоћник - противник треба усмерити ка објекту јер се субјекат ствара око објекта. Адресант, па чак и адресат у крајњем случају помоћник или противник, могу бити апстрактни, док је субјекат увек живо биће. Субјекат је оно или онај око чије се жеље организује радња, то јест - по налогу адресанта, субјекат тежи да задобије објекат у корист адресата. Актанцијални троуглови настају када нису у функцији све кућице актанцијалног модела. Након објашњавања актанцијалног модела наставник свакој групи даје наставни лист са питањима и задацима везаним за дело.

Прва и друга група ученика имају исти задатак: да направе актанцијални модел полазећи од капетана.

Трећа група ученика, коју чине ученици напредног нивоа, има задатак да примени актанцијални модел тако што ће направити два актанцијална троугла у чијем ће центру бити капетан и чудовиште. Наставник ће ученицима објаснити да актанцијални троуглови настају кад актанцијални модел престанемо да посматрамо као скупину од шест кућица и узмемо само одређен број кућица које одговарају односу који анализирамо и приказујемо.

Резултати рада група:

\section{Прва група}

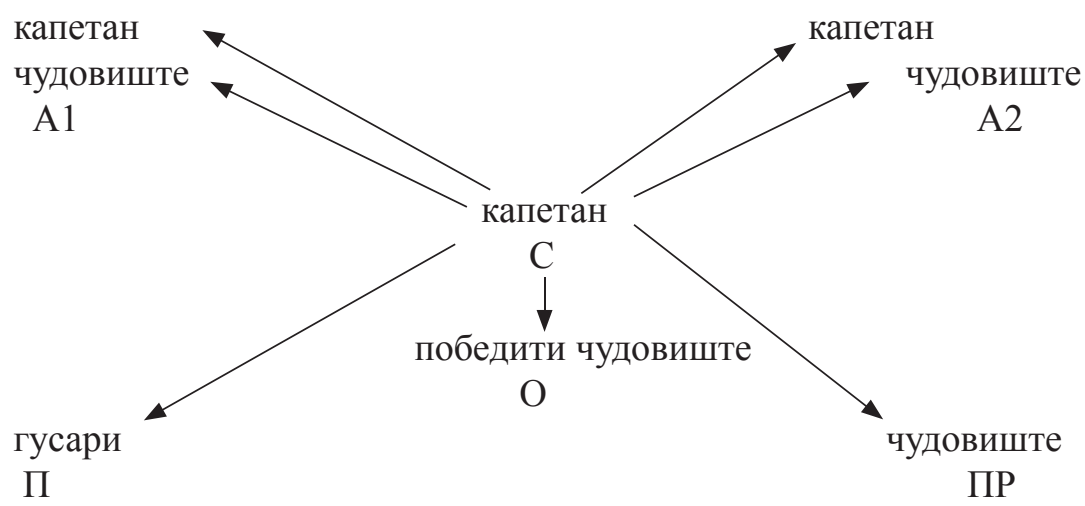

Прва група открива да је капетан субјекат чији је циљ да победи чудовиште које су препознали као објекат. Издвојили су два адресанта капетана и чудовиште објашњавајући да и капетан и чудовиште шаљу поруке један другом и зато су их ставили и у адресате. Као помоћнике субјекта, капетана, препознали су гусаре, а као противнике капетана чудовиште. 


\section{Друга група}

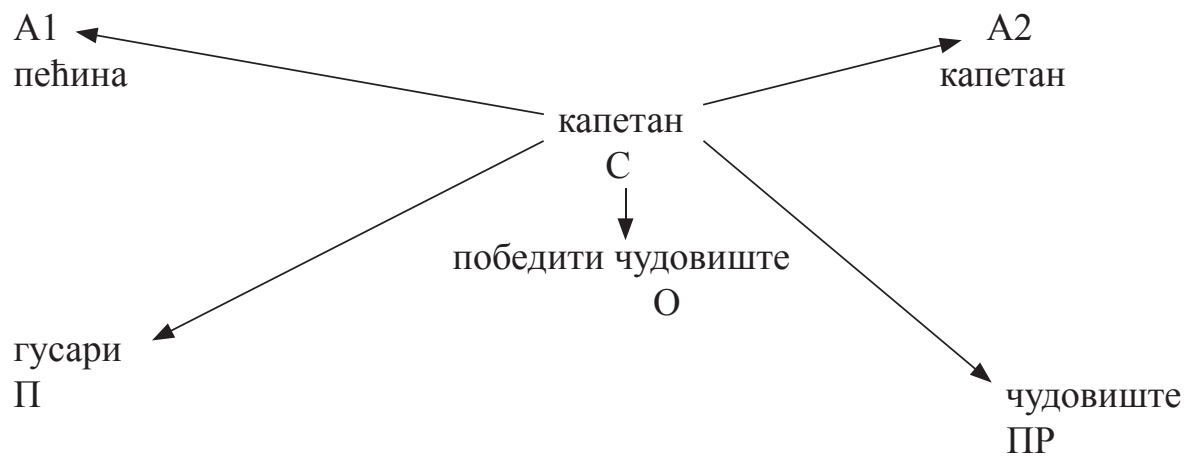

Друга група је капетана препознала као субјекат, победу чудовишта као објекат, а као адресанта пећину зато што се њој обраћа капетан и од ње добија информације за даље поступке и зато су капетана ставили као адресата. Гусаре су препознали као помоћнике капетанове, а чудовиште као противника.

\section{Tpeћа група}

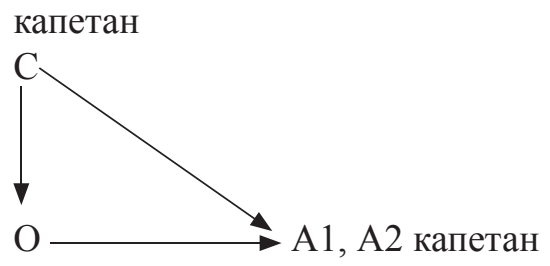

победити

чудовиште

чудовиште

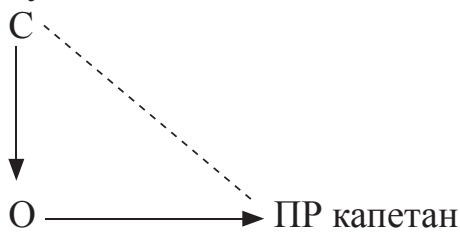

победити

капетана 
Трећа група је направила два троугла, први је идеолошки троугао по коме се радња драме гради у име једног корисника, пажња се не посвећује пореклу радње већ смислу заплета. Овде имамо и елементе психолошког троугла, где до изражаја долази чињеница да објекат није изабран само на основу субјектових склоности, већ и друштвено-историјских околности у које је и субјекат укључен. Други троугао је активни троугао, противник (капетан) је противник субјектове (чудовиште) жеље у односу на објекат (победа капетана).

У првом троуглу ученици су препознали капетана као субјекат, победа чудовишта је објекат, адресант и адресат је капетан зато што су поруке које се шаљу и добијају упућене капетану.

У другом троуглу су чудовиште препознали као субјекат, победу капетана као објекат, а капетана као противника. Изоставили су адресанта и адресата зато што сматрају да се комуникација врши директно између капетана и чудовишта.

Ученици презентују резултате групног рада и сви ученици, без обзира којој групи припадају, учествују у анализи резултата тако што саопштавају своје утиске и запажања. Током презентовања и образлагања актанцијалног модела до ког су дошли ученици одговарају на питања и задатке која се односе на карактеристике дела, а које је добила свака група на почетку часа.

Питања и задаци:

Који књижевни род и коју књижевну врсту препознајете?

Како бисте дефинисали тему одломка?

Издвојте ликове и покушајте да урадите карактеризацију ликова. Своје исказе поткрепите цитатима из дела, а можете и да их образложите ситуацијама из скеча са почетка часа.

Направите схему дијалога који се воде у одломку. Ко све ступа у разговор?

Објасните шта је смешно у одломку? Свој одговор поткрепите цитатом из одломка.

Прикажи редослед збивања у тексту кроз симболичне цртеже.

Објасните шта вам се и зашто допало у овој радио-драми.

Уочите необичности гусара и набројте их. Одговор образложите.

Замислите чудовиште, замислите музику и звуке који би најавили излазак чудовишта на сцену. Да ли се ваша замисао слаже са изласком чудовишта на сцену у скечу са почетка часа?

Анализирајте лик капетана, посебно његов дијалог са седмоглавим чудовиштем. Шта је ту смешно?

Зашто је капетан победио чудовиште? Свој одговор образложите детаљно. 
Да ли је капетан играо на срећу у борби са чудовиштем? Свој одговор образложите.

Издвојте дидаскалије и објасните њихов значај.

Покушајте да дефинишете радио-драму?

\section{Завршни део (5 минута):}

У завршном делу часа ученици све три групе прилажу схеме које су направили и сачињавају пано.

\section{Домаћи задатак:}

Подела ученика у групе остаје иста. Задатак за све три групе је исти: на основу одломка „Капетан Џон Пиплфокс“ Душка Радовића из Читанке направити луткарску представу. Прва група је обавезна да направи мапет лутке које је могуће сашити од разних врста материјала, од чарапа, рукавица... Важно је да ученици током извођења луткарске представе воде рачуна о кретању лутке, али и о гласу, односно саопштавању текста. Кад ученик луткар скривен иза паравана казује текст, лутка коју публика види мора синхронизовано да отвара уста како би се стекао утисак да лутка говори.

Друга група има задатак да направи гињол лутке које се праве од сунђера. Води се рачуна да се остави довољно места у унутрашњости лутке како би ученик могао да стави руку и покреће лутку. Гињол лутке имају отвор за врат и руке, ученик у те отворе ставља прсте и на тај начин покреће и оживљава лутку.

Трећа група има задатак да направи лутке на штапу које се могу направити на више начина, нпр. техником папир маше. Осмисли се облик лутке који се даље прави помоћу балона, лопте, жице, пластичних флаша, делова дрвета (служе као основа). Новинска хартија се исече на траке или се исцепка, натопи се лепком, а затим се лепи на изабрани предмет и на тај начин се обликује лик лутке. Након сушења лутка се боји по потреби, додају се и непоходни детаљи. Овом техником се може правити и сцена, тј. предмети потребни за сцену, нпр. намештај. За папир маше технику користи се бели лепак за дрво помешан са водом у односу $3 / 4$ лепка према $1 / 4$ воде, а може се направити и лепак од брашна и воде тако што се помешају брашно и вода у односу 1:1, а може се један део брашна помешати са водом, затим се кува до кључања, кад се охлади може се користити. Ученици могу да користе и лепак за тапете. Важно је да се не нанесе више од четири слоја папира и да се све добро осуши пре бојења и детаља. За бојење се могу користити водене бојице, темпере, акрилне боје за зидове. Да се боја не би скидала лутку би било добро прелакирати безбојним лаком. Кад наставник упозна ученике са 
свим овим детаљима добро је и да им напомене да лутка мора да има карактер и да морају да воде рачина о свим појединостима (ако праве лутку на штапу где ће ставити штап како би лутка била функционална).

Током израде лутака водити рачуна о карактеру лутке који мора бити у складу са изгледом лутке. Лутке које се буду појављивале на сцени морају бити осмишљене тако да могу да ураде све што је у тексту наведено. Свет луткарства представља свет онеобичавајуће анимације сценске поезије. Луткарство је уметност тоталног театра. Сценске лутке изражавају свет игре, дух облика, тајновиту анимацију предмета, слика и сазвучја; говор знакова на сцени. Луткарство је позориште сажетости, лапидарне маште, лаконске изразитости. Луткарски театар је „хаику“ позориште сведено на есенцијални аудио-визуелни израз. Луткарство претвара мртву природу у раскошно дело живе сценске уметности (Лази: 2007).

Важно је да и сцена буде осмишљена, да оба платна (горње платно које најчешће представља небо и предње платно које најчешће представља земљу) буду детаљно осмишљени, а у складу са изгледом лутака. Ученицима је потребно скренути пажњу и на значај звучних и светлосних ефеката. Звучни ефекти могу да најаве догађаје и да представи дају посебан значај. Светлосним ефектима се може назначити долазак новог дана или се може осветлети једна лутка која у одређеном моменту у представи има посебан значај.

Ученицима је потребно време како би успешно урадили овај домаћи задатак. Зато је најбоље да се наставник договори са ученицима да луткарску представу спреме за крај школске године. Током стварања луткарске представе ученици међусобно сарађују и на тај начин остварују вршњачко учење, а наставник има улогу саветника. Наставник усмерава ученике, подржава их и мотивише. Наставник ученике може да усмери и на часове луткарске секције, па да у оквиру часова ваннаставне активности реализују домаћи задатак.

\section{4. ЗАКљУЧАК}

Оваква разрада наставне јединице омогућава савремени приступ обради драмског дела, али и примену класичних наставних метода и облика рада. Применом актанцијалног модела и вршњачког учења ученицима је омогућено да међусобно сарађују, да подржавају једни друге, да предлажу, истражују, закључују, повезују и примењују раније стечна знања. Ученици који остварују позитивне резултате на основном и средњем нивоу образовања имали су пред собом захтеве који су у складу са њиховим способностима, а ученици који задовољавају критеријуме напредног нивоа имали су пред собом изазов. 
Ученици који су талентовани и надарени за предмет српски језик имали су прилику да своје знање и способности директно пренесу својим вршњацима и да кроз отворену и директну сарадњу и подршку заједно дођу до нових сазнања, закључака и резултата. Поред актанцијалног модела у редовној настави српског језика могуће је применити и многе друге облике и начине рада како би се драма и сценска уметност приближиле ученицима и како би ти часови били квалитетнији. Домаћи задатак је осмишљен тако да ученицима приближи луткарство као посебну врсту сценске уметности и да се направи корелација редовне наставе српског језика са ваннаставним активностима, луткарском секцијом, а да се поштују принципи вршњачког учења. Ученици кроз игру упознају луткарство, кроз игру мисле, сазнају, стварају, откривају.... Лутка као једно од основних обележја детињства има велики значај и утицај на свако дете. Ученици стварају лутку, затим је оживљавају. Лутка у ученичким рукама може да буде и гладна и жедна, и добра и лоша, и лепа и ружна... На овај начин се код ученика буди љубав не само према сценској уметности, већ љубав према уметности уоште. Кроз спој драмског књижевног дела и луткарске представе ученици спознају значај и лепоту сценске уметности, схватају њену ширину и чињеницу да сценска уметност у себи садржи много више од пуке глуме.

\section{ЛИТЕРАТУРА}

Викторовић, О. (2004). Драмске радиониие 1. Београд: ЗУНС.

Викторовић, О. (2005). Драмске радиониие 2. Београд: ЗУНС.

Викторовић, О. (2005). Драмске радионище 2: приручник за наставнике. Београд: ЗУНС.

Викторовић, О. (2006). Драмске радионице 3. Београд: ЗУНС.

Викторовић, О. (2004). Драмске радиониче 1: приручник за наставнике. Београд: ЗУНС.

Вилотијевић, М. (1998). Врсте наставе. Београд: Учитељски факултет. Иберсфелд, А. (2000). Кључни термини позоришне анализе. Београд: Центар за ново позориште и игру.

Иберсфелд, А. (1982). Читање позоришта. Београд: „Вук Караџић“.

Игњатовић, С. (1960). Дечја радозналост и юено неговање. Београд: Рад.

Илић, П. (1997). Српски језик и књижевност у наставној теорији и пракси: методика наставе. Нови Сад: Прометеј.

Квашчев, Р. (1977). Како развити стваралачке способности. Београд: БИГЗ. Лазић, Р. (2002). Естетика луткарства. Београд: БатАтисак. Лазић, Р. (2007). Култура луткарства. Београд: ФотоФортуна. 
Лазић, Р. (2010). Луткарски театрум мунди: мала театрологија луткарства. Београд: Фото Футура.

Лазић, Р. (2007). Магија луткарства: драматургија и поетика луткарског театра: антологија. Београд: Фото Футура.

Лазић, Р. (1991). Трактат о луткарској режији. Нови Сад: Прометеј.

Лазић, Р. (2007). Уметност луткарства: у потрази за естетиком луткарског театра. Београд: Фото Футура.

Лазић, Р. (2003). Уметност редитељства: увод у теорију режије: позориште, драма, опера, балет, луткарство, филм, радио, телевизија, мултидисциплинарна режија. Нови Сад: Позоришни музеј Војводине.

Маринковић, С. (2003). Методика креативне наставе српског језика и књижевности. Београд: Креативни центар.

Хавелка, Н. (2000). Ученик и наставник у образовном процесу. Београд: Завод за уџбенике и наставна средства.

\section{MA Marija M. Bjeljac}

\section{A METHODOLOGICAL APPROACH TO THE TEACHING UNIT “CAPTAIN JOHN PEOPLEFOX” BY DUŠKO RADOVIĆ THROUGH THE APPLICATION OF THE ACTANTIAL MODEL}

\section{Summary}

This paper presents a teaching interpretation of an excerpt from the literary work "Captain John Peoplefox" by Duško Radović taught in the fifth grade of primary school. Special attention is given to acting out the excerpt with the intention of motivating students to read the whole work and to take active part in its analysis. The paper emphasized the importance of implementing the actantial model in the analysis of a literary work, differentiated teaching and peer support that offer the teacher a possibility of teaching literary texts in an interesting and creative way and thus motivating students to read literature, as well as enabling them to take active part during the lessons in which a new material is presented. A combination of the Serbian language classes, extracurricular activities and puppet clubs develops the students' understanding and love of acting.

Key words: excerpt analysis, actantial model, differential teaching, peer learning, puppet show, puppet club. 